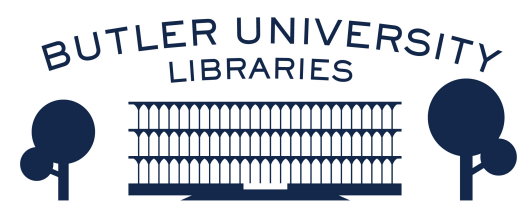

Journal of Hindu-Christian Studies

\title{
Issues in Christian Encounters with Yoga: Exploring 3HO/ Kundalini Yoga
}

\author{
Michael Stoeber \\ Regis College, University of Toronto
}

Follow this and additional works at: https://digitalcommons.butler.edu/jhcs

Part of the Christianity Commons, and the Religious Thought, Theology and Philosophy of Religion Commons

\section{Recommended Citation}

Stoeber, Michael (2017) "Issues in Christian Encounters with Yoga: Exploring 3HO/Kundalini Yoga," Journal of Hindu-Christian Studies: Vol. 30, Article 3.

Available at: https://doi.org/10.7825/2164-6279.1655

The Journal of Hindu-Christian Studies is a publication of the Society for Hindu-Christian Studies. The digital version is made available by Digital Commons @ Butler University. For questions about the Journal or the Society, please contact cbauman@butler.edu. For more information about Digital Commons @ Butler University, please contact digitalscholarship@butler.edu. 


\title{
Issues in Christian Encounters with Yoga: Exploring 3HO/Kundalini Yoga
}

\author{
Michael Stoeber \\ Regis College, University of Toronto
}

\begin{abstract}
:
THE paper begins by drawing out current issues that have been raised by critics concerning the contemporary practice of Hindu postural types of yoga in western and specifically western Christian contexts, with some illustrative reference to contemporary movements and schools, especially to Bikram Yoga. These are: cultural misappropriation; commodification; lack of moral pre-requisites; narcissistic attachment to bodily effects; occult influences; and doctrinal differences. The paper then explores specific aspects of the theory and practice of $3 \mathrm{HO} /$ Kundalini Yoga $(3 \mathrm{HO} / \mathrm{KY})$ by Christians in light of these possible issues, showing how this tradition of Kundalini Yoga seems to skirt or side-step most of them, simply by the way that it locates and grounds itself in
\end{abstract}

Sikhism. The substantial concerns for Christians practicing $3 \mathrm{HO} / \mathrm{KY}$ seem related to issues surrounding doctrinal compatibility and religious syncretism-criticisms that have been raised also by some sikhs against $3 \mathrm{HO} / \mathrm{KY}$ itself.

\section{Introduction}

Since the 1960s, postural types of yoga have been popularized especially in larger urban settings in the Western world. These are yogas which are thought to have evolved from Hatha Yoga, which itself emerged perhaps around the $10^{\text {th }}$ or $11^{\text {th }}$ century of the common-era, emphasizing various physical body postures and breathing techniques. More popular major yoga schools in the West today include Iyengar Yoga, Ashtanga Vinyasa Yoga, Integral Yoga, Sivananda Yoga, Bihar Yoga, and Bikram Yoga. ${ }^{1}$ Plus, there are many independent teachers

Michael Stoeber is professor of spirituality and philosophy of religion at Regis College and crossappointed to the Department for the Study of Religion, University of Toronto. His main areas of teaching and writing are the nature of religious experience, issues in comparative mysticism, and problems of evil and suffering. His current research explores topics on the intersection of spirituality and art, and comparative issues in meditation, prayer, and yoga, across religious traditions. Alongside three books, recent essays have appeared in the Toronto Journal of Theology ("Mysticism in The Brothers Karamazov"), European Journal for Philosophy of Religion ("Exploring Processes and Dynamics of Mystical Contemplative Meditation", also translated into Russian in Philosophy of Religion: An Almanac 2014-2015), and an edited volume called Mystical Landscapes: Vincent Van Gogh to Emily Carr ("Mystical Concepts, Artistic Contexts", also translated into French). His "The Comparative Study of Mysticism”, The Oxford Research Encyclopedia of Religion (New York: Oxford University Press, 2015 [updated 2017]), has been translated in the Russian periodical, Philosophy of Religion: Analytic Researches (forthcoming 2017). 
offering yoga classes of various kinds. In these contemporary contexts, yoga is thus practiced regularly by non-Hindus-as well as by secularized westerners, those who have lapsed from their faith, and/or those who are associated with the New Age movement. Indeed, a number of organizations have developed amongst some Christians and Jews who practice yoga-such as Holy Yoga and Jewish Yoga Network. ${ }^{2}$ But, quite apart from such formal associations, many westerners of various degrees of institutional commitment to their Jewish and Christian denominations are involved in regular, traditionally Indian, yoga practices.

For the most part, responses to the Christian practice of yoga by Hindu and Christian institutional authorities have been cautiously suspicious and critical. Christian authorities tend to highlight the psychological and spiritual dangers of yoga and its divergence from Christian doctrine, while the Hindu leaders tend to focus on what they take to be the western corruption of traditional yoga theory and practice. Specifically, these issues include: cultural misappropriation, commodification, lack of moral pre-requisites, narcissistic attachment to bodily effects, occult influences, and doctrinal differences. In section 2, I will briefly describe these issues with some illustrative reference to contemporary movements and schools, especially to Bikram Yoga, before exploring them specifically in relation to $3 \mathrm{HO} / \mathrm{Kundalini}$ Yoga $(3 \mathrm{HO} / \mathrm{KY})$ in section $3 .^{3}$ I will show how $3 \mathrm{HO} / \mathrm{KY}$ seems to avoid most of these issues through its Sikh contexts and I will consider also the significance of issues of doctrinal differences for Christians practicing $3 \mathrm{HO} / \mathrm{KY}$.

\section{Issues Raised Concerning Yoga Practice in the West}

Cultural Misappropriation: In 2008, the Hindu American Foundation launched a "Take Back Yoga Campaign", which raised the question of yoga ownership in light of the contemporary integration of yoga with non-Hindu faiths or claims of its dissociation from religion altogether. ${ }^{4}$ One of the criticisms is a general accusation of "cultural misappropriation", where westerners are perceived to have stolen elements of an intrinsically or definitively Hindu religious tradition, which is regarded as improper and wrong, regardless of the apparent support or benefits of the practice for the nonHindu practitioner.

For example, this seems to be an essential aspect of the rationale behind the November 2015 cancellation of a long-running yoga class at the University of Ottawa in Canada by its university Student Federation. Student authorities argued "that the cultures that yoga is taken from, "have experienced oppression, cultural genocide and diasporas due to colonialism and western supremacy'. They said '...we need to be mindful of this and how we express ourselves while practising yoga"'. Although in this case the instructor claimed to be focusing solely on the physical aspects of yoga, concerns were also raised that some yoga instructors misrepresent spiritual aspects of the practice. Student federation president Romeo Ahimakin responded: “...We are trying to have those sessions done in a way in which students are aware of where the spiritual and cultural aspects come from, so that these sessions are done in a respectful manner." 5

In contrast to such apologetic positioning towards Hinduism, there are western groups that claim that the essentials of yoga are 
separable from the spiritual/religious aspects of Indian religions, and so compatible with any non-Indian religion. This is well illustrated in the Christian group Holy Yoga, which employs from yoga only breath, posture, and meditation practices, and explicitly excludes all reference to Indian theory in incorporating strictly Christian doctrine. Commentary on their website highlights well this kind of adaptation:

We know that yoga is a spiritual discipline much like fasting, meditation, and prayer that cannot be owned by one specific religion. While yoga predates Hinduism, Hindus were the first to give yoga a written structure. Yoga postures were originally named in Sanskrit. Holy Yoga teaches their instructors to teach in their native tongues to avoid any confusion or becoming a stumbling block. Holy Yoga embraces the essential elements of yoga: breath work, meditation and physical postures. In all of these elements, Christ is the focus of our intention and worship. There are other concepts and traditions that may be part of some yoga practices that are not typically a part of Holy Yoga, such as chanting "OM" or using chakra theory to explain the interplay of the physical and energetic dynamic in the human body. ${ }^{6}$

Commodification: A related, second, criticism is that Hindu yoga has been usurped by the tenets of western capitalism, where the economic market has co-opted the traditional spiritual practice of Hindu yoga and transformed it into a consumer item intended primarily for material profit. This colors it negatively in various ways, for example, specifically with Bikram Choudhury copyrighting a sequence of 26 traditional postures and movements, labeling it "Bikram Yoga", and suing other yoga practitioners for copyright infringement. His estimated net worth from his yoga practice which began in the 1970s is $\$ 75$ million and it is reported he earned royalties estimated at \$7-10 million per year through certified instructors who operate affiliated studios. $^{7}$ In this context, critics would argue, a Hindu religious tradition has been distortedly transformed into a commercialized multi-million dollar business empire, one that is centered on economic profit and focused solely on physical postures and movements, where its traditional association with Hindu religion has been virtually severed.

Moral Pre-requisites: This relates to a third criticism: the neglect or denial in contemporary western yogas of the moral pre-requisites of traditional Hindu yoga and a lack of concern for ethical conduct amongst teachers and practitioners. This point is also highlighted in the case of Bikram Choudhury, who, over and above these issues of the western commodification of yoga, lost in 2016 a sexual harassment case in Los Angeles, where he was accused of being a "vile sexual predator" in relation to some of his female students. Minakshi Jafa-Bodden, Choudhury's past legal advisor, was awarded more than \$6.4 million compensation by a jury in Los Angeles, for gender discrimination, sexual harassment, and wrongful dismissal. In 2017, Choudhury claimed he was bankrupt and, later, an arrest warrant was issued for him in California within the context of that 2016 decision. ${ }^{8}$

There is no reference in Bikram's teachings to the kinds of moral requirements and concerns one finds associated traditionally with Hindu yoga, such as the yamas-moral imperatives-in 
Patanjali's Yoga Sutra: the cultivation of peacefulness or compassion (ahimsa); truthfulness (satya); honesty (asteya); sexual restraint (brahmacharya); and generosity or nonpossessiveness (aparigraha). Some critics would argue that such ethical grounding would help to deter the kinds of sexual improprieties or distortions of which Bikram is being accused. More generally, critics argue that contemporary yoga enthusiasts in the west are being taught yoga that has been stripped from its essential religious-spiritual components, features that would ensure a socio-moral context. ${ }^{9}$

Narcisstic Attachments: Moreover, in overemphasizing the physical practices and effects of yoga, some critics argue that western appropriations actually support or encourage a narcissistic attachment to bodily effects-a preoccupation with one's own physical fitness, attractiveness and achievements. This fourth concern is highlighted in the popularity of what they call "yoga sports". Bikram Choudry himself in his teens apparently won three consecutive National India Yoga Championships-which also indicates that this is an issue that applies to Indian contexts, as well as in the West. The Indian Yoga Federation has a number of affiliated associations that hold regular yoga competitions in different regions of India. Its objectives include: "To promote, encourage, popularize, standardize and supervise of yoga sports in the all country" and "To arrange \& promote the Yoga meet/competition, camp, seminars and contests" $[\text { sic }]^{10}$

Bradley Malkovsky observes how some yoga teachers he has encountered have been preoccupied with their youthful beauty, obsessed by their exceptional physical conditioning, or inflated by the sense of their own physical size and power. He writes: “They are drill sergeants masquerading as yoga teachers. They are practicing what should be called a "military yoga". "...They are not interested in meditation or spiritual development". ${ }^{11}$ Roman Catholic institutional authorities refer to this phenomenon as an overvaluation of what they call "psychophysical symbolism". For the Congregation for the Doctrine of the Faith (CDF), this phrase seems to refer to the effects that "the position and demeanor of the body" has on the person practicing yoga or some form of meditation. In their view, the danger is that such practices might "degenerate into a cult of the body", where the body becomes "an idol". ${ }^{12}$ Such distortions, the CDF claims, can even "lead surreptitiously to considering all bodily sensations as spiritual experience"where they presumably mean that enhanced bodily feelings are mistaken for authentic mystical experience. ${ }^{13}$

The CDF also relates these issues surrounding the inflated or narcissistic treatment or status given to the body in yoga to the question of moral prerequisites for yoga practice. They speak of "a kind of mental schizophrenia which could lead to psychic disturbance and, at times, to moral deviations", when people who are not morally developed or advanced grant spiritual significance to certain heightened bodily experiences. ${ }^{14}$ I take it that they mean here that the heightened spiritual experiences of the person lead to a false sense of superiority associated with an inflated ego, one that issues forth in destructive relations with others. I would add to this concern that, if it is true that a person advanced in yoga practice can actually channel the affective energy or consciousness of such ecstatic spiritual experience to others, as is sometimes claimed, then one can see how spiritual narcissism 
amongst some yoga teachers could cause harm to others. In contrast, when concerns about moral character-development are drawn essentially into yoga practice, this helps to lessen the dangers of such radical self-inflation.

Occult Influences: Some Christians would go so far as to claim that such a radically narcissistic focus on physical enhancement and self-empowerment actually opens a person to demonic influences. Evangelical leader Mark Driscoll and other authorities take an extreme perspective on this, suggesting that yoga is always demonic. Driscoll writes: "If you sign up for a little yoga class, you're signing up for a little demon class. That's what you're doing. And Satan doesn't care if you stretch, as long as you go to hell". ${ }^{15}$ Other critics, like Malkovsky, acknowledge the significant benefits of yoga, while noting possible occult dangers, depending on how one approaches the practice. He suggests that such negative influences by spirits might even be more prominent amongst practitioners who do not take these possibilities seriously. ${ }^{16}$ Their naïve attitude toward the content and dynamics of the spirit-world puts them at greater risk of being unconsciously influenced in negative ways.

Another explanation suggests possible negative influences from the shadow side of the personal or pre-personal unconscious. Some transpersonal theorists argue that certain yogic practices and other forms of meditation act to unhinge normal filters of the ego that typically repress features of the instinctual-archetypal unconscious. In Jungian and transpersonal theory, archetypes, which typically reveal themselves in images in dreams, are very powerful autonomous primal energies of the collective unconscious-beyond one's personal unconscious-that act to shape consciousness and influence personal development. In this view, ideally, archetypal content becomes integrated with other aspects of the psyche. However, practitioners can find themselves overwhelmed by such powerful energyespecially related to primal survival instincts that in Christian spirituality have traditionally have been understood as demonic realitieswhich are brought to consciousness through yogic and other meditative practices. Valentin Tomberg, for example, warns that there is always the danger that an archetype can "invade, inundate and engulf consciousness", rather than achieving an integrative "accommodation with the unconscious". "...Therefore, inflation constitutes the principle danger and trial for occultists, esotericists, magicians, gnostics and mystics. Monasteries and spiritual orders have always known this,...". ${ }^{17}$

Doctrinal Differences: The CDF does not mention explicitly these "occult" dangers of yoga practice associated with the "demonic", but it does warn against doctrines that diverge from Christian perspectives, citing for example the goal of self-absorption or dissolution in the Divine, in contrast to Christian ideals of mystical union, which always maintain some sense of otherness, even within a condition that shares in the divine nature through what they call "perfect" union. ${ }^{18}$ It also highlights certain Christian doctrine that provides the overriding criteria for a Roman Catholic who practices yoga. It insists that a Catholic can take from the "great [non-Christian] religions" "what is useful so long as the Christian conception of prayer, its logic and requirements[] are never obscured". ${ }^{19}$ This view parallels Thomas Matus's insightful observations, that:

Yoga belongs to the order of optional means, even though it has its own 
intrinsic end, which, in the concrete situation, can be made to coincide with the ultimate end of the Christian: loving union with God through Jesus Christ in the Holy Spirit. In this sense, a Christian understanding of yoga means the perception of the Christian end in all the means employed and experiences had throughout the yogic quest. ...What is at issue here is the use of yoga as an aid in dedicating one's whole being to Christ and in fulfilling Christ's law of loving service to one's neighbor. ${ }^{20}$

For the CDF, this focus includes a sense of communal connection with and support for other Christians and an ongoing commitment to universal love within a framework of prayer that is always colored and modeled by the reality of Jesus Christ. Related to such formal ecclesiological prescriptions, from a practical point of view, it seems to me that key questions for a Christian practicing yoga would be: (1) Do these yoga practices inspire and arouse beneficial types of embodied spiritual experiences that would not otherwise obtain? (2) Do they support or augment the experience and communication of the love of Christ? (3) Do they force one to contradict essential Christian practices and beliefs? ${ }^{21}$

\section{Christians Practicing 3HO Kundalini Yoga}

Kundalini Yoga and Sikhism: I turn now to explore these issues as they might relate to Christians specifically practicing $3 \mathrm{HO} / \mathrm{KY}$. Established in North America in 1969 by Yogi Bhajan (Harbbhajan Singh Puri), 3HO was established as a tax-exempt educational organization concerned with the "health", "happiness", and "holiness" of its members, especially by drawing upon Sikh socio-moral values and practicing Kundalini Yoga. ${ }^{22}$ 3HO/KY involves many hundreds of different specific kriyās (sets of practices) that have been taught by Yogi Bhajan and collected by his students in different publications over the last four decades. This collection of yoga sets is vast and impressive. These kriyās include many different breathing techniques (prāṇāyāma), movements and body postures (asanas), hand positions (mudras), mental and devotional foci (dhyāna and bhakti), and sacred chants (naad). Despite the multitude and diversity of sets, 3H0/KY does not appear to be a disconnected mishmash of yogas, but seems very fluid and integrated, with a complex and well-organized system.

$3 \mathrm{HO} / \mathrm{KY}$ is trademarked (i.e. Kundalini Yoga as taught by Yogi Bhajan ${ }^{\circledR}$ and White Tantric Yoga ${ }^{\circledR}$ ), with practices in each set-which are carefully timed and structured-intended to aid in the healing or transformation of some specific aspect of the person, for example, to: balance sexual energy; reduce emotional depression, stress, anxiety, anger, negative thoughts, or negative feelings; resist illnesses and addictions; enhance prana (vital energy or life-force); support prana-apana balance; stimulate love, or healing, or compassion, or inner stamina and vitality; strengthen the nervous system; etc. However, these specific intentions of kriyas are always framed within an over-riding ideal of union of one's spiritual self with Sat Guru-the divine Reality in Sikh tradition. As Guru Raj Kaur Khalsa describes this process of growth towards and into God:

A Sikh does not do yoga to "earn" his or her liberation. A Sikh uses the techniques of Kundalini Yoga in the same way that s/he would take a bath in the morning, or be conscious of how $\mathrm{s} /$ he maintains the body purely, eating a 
vegetarian diet, not partaking of tobacco or alcohol. In other words, [through the practices of Kundalini Yoga] a Sikh prepares this sacred body temple as purely as possible to bring the Holy Naam, the Holy Gurbani [works of the Guru] into it, to do justice to the Sacred Word. ${ }^{23}$

It is hard to say precisely how these practices of Kundalini Yoga differ from those of other popular contemporary yoga schools, without further careful analysis of the different groups, but I can say that 3HO/KY emphasizes certain major elements. With some exceptions, the vast majority of kriyas are performed with eyes closed, where breathing is done through the nose and often accompanied by silent parallel mantra repetition, and where most sets include meditative components, periods of integrative relaxation, and vocal chanting that is colored by a bhakti approach to the dynamic within the context of traditional Sikh practices. In contrast to other contemporary postural yoga schools in the West, 3HO/KY is explicitly aligned since 1973 with a non-profit Sikh denomination-Sikh Dharma International (SDI) - with the approval of Sikh authority-the Alkal Takhat in Amritsar, India. Its mission most generally is "sharing the universal teachings and lifestyle of the spiritual path of Sikh Dharma through service, education, and community so that one can experience their divinity, spirit, and fulfillment". ${ }^{24}$ SDI seems to be the most central of seven "Legacy Organizations" that Yogi Bhajan "built" in his lifetime (along with others he instituted or inspired), which also include the non-profits $3 \mathrm{HO} / \mathrm{KY}$, Kundalini Research Institute, Miri Piri Academy, SikhNet, and the for-profit companies Yogi Tea and Akal Security. ${ }^{25}$
I will briefly explore the significance of the relationship of $3 \mathrm{HO} / \mathrm{KY}$ to these for-profit organizations below with respect to questions surrounding the commodification of this yoga. However, I note here that most of the leaders of $3 \mathrm{HO} / \mathrm{KY}$ and some of the teachers participate in traditional Sikh practices and beliefs, including regular dawn meditation (Amrit Vela), undergoing Sikh initiation (Amrit Sanskar), practicing Sikh ethical teachings, wearing Sikh attire (Bana), and observing Sikh holy days, all in conformity with major guidelines set forth in the Sikh Rahit Maryada-the major Sikh code of discipline established in 1950. Although one can find on the internet some vitriolic criticisms of what researchers have labeled these "Gora" or "white" Sikhs (thus reflecting their practice of wearing white attire)-especially in their emphasis on Kundalini Yoga-Verne Dusenbery observes a positively developing relation between Punjabi Sikhs and Gora Sikhs on a number of important fronts, while Pashaura Singh notes that "Punjabi Sikhs in general praise the strict Khalsa-style discipline of the White Sikhs". ${ }^{26}$

$3 \mathrm{HO} / \mathrm{KY}$ is linked with Sikh spirituality especially in its emphasis upon Mantra Yoga (sound formulas) or Naad Yoga (mysticism of sound) associated with Sikhism. Feelings of reverential self-surrender and devotional humility might be inspired through such chanting. $3 \mathrm{HO} / \mathrm{KY}$ draws especially upon traditional Sikh prayers (japji), in its focus on this sounding or voice meditation, encouraging practitioners to strive to become open to the sacred sound of the divine Presence-the Shabd Guru within. To give just one example, each class begins with an intentional grounding in Sikh spirituality, as students chant three times in communion, "Ong Namo Guru Dev Namo", a 
Gurmukhi phrase that means "I bow to the unfolding creative consciousness, I bow to the divine teacher within me and surrounding me". This reverential prayer is intended to help shift one's attention away from the ego towards the spiritual self in relation to the divine Word, and to begin to align oneself with past spiritual "masters and saints" who have supported this practice. In line with Sikh teachings, there are in many $3 \mathrm{HO} / \mathrm{KY}$ yoga sets exhortations to dependence on a divine Reality and to a radical self-giving, especially in the context of sacred chanting, which includes honor to and the support of ultimate Reality or the divine Guru, the historical Gurus, and Sikh sacred scripture (Siri Guru Granth Sahib), to which one is called ultimately to surrender oneself completely in love.

Narcisstic Attachments; Occult Influences; and Moral Pre-requisites: Such connection to traditional Sikhism would appear to provide some protection for students against tendencies towards narcissistic attachments to bodily effects. It encourages a self-awareness and improvement of one's moral/ethical character and helps to safeguard against delusions associated with non-spiritual experiences and unconscious or perhaps even demonic distortions, as well as ego-inflation. In my experience, $3 \mathrm{HO} / \mathrm{KY}$ teachers generally are well trained, professional, and accessible to students with questions regarding resistances, obstacles, and other dynamics of their practice, though of course the depth and quality of such direction or counsel will vary. The teacher's manual and other group literature give much attention to Sikh socio-moral values and development, including codes of excellence, professional standards, and ethics for teachers, ${ }^{27}$ though most teachers are not formally Sikhs and, in my experience, Sikh Dharma members do not actively proselytize their Sikhism. Moreover, group literature stresses the social and spiritual significance of monogamous relationships and family dynamics, in classifying Kundalini Yoga as a "householder's" yoga.

For example, various articles in the in-house publication, Beads of Truth: The Magazine of the $3 \mathrm{HO}$ Foundation-which was published tri-annually from 1970 to the early 1990s-encouraged Sikh socio-moral values. This magazine included a number of informative articles on the themes of marriage, infants and children, parenting, and education, with whole issues devoted to some of these themes-as well as regular columns on diet and nutrition. The journal included: lectures by Yogi Bhajan and other leaders of the group on various social and religious subjects; short essays on Sikh Gurus, history, scripture, holy days, beliefs and rituals; instructions on yoga practices; information about the group's events; and accounts of Yogi Bhajan's travels and activities. Clearly responding to the special needs of the counter-cultural "hippie" community in the early years of the movement-many of whom had left home at a very young age and were without the guidance and support of experienced elders-this publication became more and more colored by the relatively conservative socio-cultural context of Yogi Bhajan's Punjabi Sikhism, stressing the importance of education, selfreliance, work, and social responsibility. ${ }^{28}$

Commodification: This linkage of $3 \mathrm{HO} / \mathrm{KY}$ to SDI, and the fact these are non-profit organizations, also function to reduce issues related to commodification, insofar as there seems to be no evidence of the spiritual intentions of $3 \mathrm{HO} / \mathrm{KY}$ being overridden by financial concerns. From the beginning, the 
yoga practices of $3 \mathrm{HO} / \mathrm{KY}$ were kept separate from such entrepreneurial activities and seem to be integrated with Sikh spirituality and theory in such a way so as to ensure against nonspiritual commercialization. The cost of teacher training and annual teacher's fees seem to be low relative to that of other yoga groups, and $3 \mathrm{HO} / \mathrm{KY}$ has never become a for-profit enterprise, though teachers do charge fees for classes ${ }^{29}$ and are encouraged to practice Gurudakshina: "tithing 11 percent of [their] yoga class earnings without expense deductions, to the source of the Teachings", as an "expression of gratitude" and a seed for one's future prosperity and in support of the spread of the teaching. ${ }^{30}$ Moreover, there are some privately owned studios that do specialize in $3 \mathrm{HO} / \mathrm{KY}$ and some that offer classes in $3 \mathrm{HO} / \mathrm{KY}$.

Although Yogi Bhajan was a successful businessperson who helped to create many businesses, which came to be worth millions of dollars, the religious components of his work always remained non-profit and formally separated from these enterprises. ${ }^{31}$ According to various newspaper articles, the assets of Yogi Bhajan's living trust were divided equally between a survivor's trust for his wife, Inderjit Kaur Puri, and an administrator's trust for fifteen of his assistants, but I have been unable to ascertain how much this was. ${ }^{32}$ Also, before his death, Yogi Bhajan created Unto Infinity-“a charitable limited liability corporation in Oregon", in charge of the non-profit Legacy Organizations, which I mentioned above, as well as of Akal Security and Golden Temple, companies that supported all of these nonprofits through donations, though I do not know the extent. ${ }^{33}$ Akal Securities is said to have earned over one billion dollars from 2006-2009 and, in 2004, 3HO Golden Temple (which was sold in part in 2007) apparently was earning 60 million annually. ${ }^{34}$ The questions about commodification surrounding $3 \mathrm{HO} / \mathrm{KY}$ are complicated by this relationship to such successful business enterprises.

Since 2001, the security company has had contracts for federal courthouses and immigration detention centers, airports, U.S. army bases, and embassies. So, although $3 \mathrm{HO} / \mathrm{KY}$ is a non-profit, and separated from entrepreneurial issues that are associated with for-profit yoga schools, it does receive some financial contributions from a company involved in U.S. law enforcement and the military, though it is unclear how much. Nicola Mooney writes of “Akal Security's collaborations within American government and military fields, which seem to permeate the $3 \mathrm{HO}$ industries", but leaders of the group see the focus on the security and protection industry-as well as the entrepreneurial energies and successes of those immersed in Sikh Dharma or of others who practice $3 \mathrm{HO} / \mathrm{KY}$-as consistent with the ethos of Sikhism and theories of Kundalini Yoga. ${ }^{35}$ For example, one of the claims in the teaching handbook is that Kundalini Yoga "is a yoga for a householder who wants to be a saint and a soldier, and prosperous and successful at the same time, taking care of everything", ${ }^{36}$ which certainly marks it off in unusual ways from other current yoga schools.

$3 \mathrm{HO} / \mathrm{KY}$ is explicitly a this-worldly focused yoga committed to physical and emotional health and material prosperity within a social context that is grounded in Sikh tradition. Still, it seems important that students recognize the relationship and financial dependence of $3 \mathrm{HO} / \mathrm{KY}$ on these specific for-profit enterprises, in case any of the activities or philosophies of these companies clash with their personal 
values and ideals. And there is always the danger that specific 3HO/KY teachers might prioritize the business-financial aspects of their classes over the spiritual ideals of the teachings, even though institutional structures are set up in ways that resist such commodification.

Cultural Misappropriation: Regarding the question of culture misappropriation, some Sikhs have criticized Sikh Dharma for introducing a "Hindu" yoga that is actually alien to Sikhism, quite apart from the question of Christians participating in the practice of $3 \mathrm{HO} / \mathrm{KY}$. So there has been some attempt by Yogi Bhajan and other leaders of the group to argue for an historical Sikh yoga tradition to which the contemporary practice is linked. In support, some scholars have highlighted the brief references to Kundalini Yoga in the Sikh scripture, Sri Guru Granth Sahib; ${ }^{37}$ and, more significantly, some 3HO/KY literature describes an ancient Sikh lineage for this form of Kundalini Yoga through a teacher, Sant Hazara Singh, connecting it to some of the Sikh Gurus and the Nāth Yoga tradition.

These claims have been questioned in recent scholarship, with the suggestion by Philip Deslippe that Yogi Bhajan's version of Kundalini Yoga is his own synthesis of the mantra teachings of another Sikh Sant with the Hatha Yoga practices of a Hindu Swami. However, it seems hard to claim that yoga is totally foreign to traditional Sikhism, simply given the Nath influences on Sikh spirituality that scholars generally acknowledge. Moreover, I would argue rather that Yogi Bhajan most likely had a number of teachers and reference to multiple texts-that his version of Kundalini Yoga has genuine roots in Sikhism, as well as in Hinduism-simply given the vast and impressive complexity of his teachings, which go far beyond these two claimed sources by Deslippe. ${ }^{38}$ Indeed, it seems quite legitimate to me to classify $3 \mathrm{HO} / \mathrm{KY}$ as a specifically "Sikh Yoga", given its integrated connection with Sikh theory and practices. In any case, the very nature of $3 \mathrm{HO} / \mathrm{KY}$ supports the argument of Andrea Jain and others, that postural types of yoga are not essentially Hindu, that yoga is highly malleable, and has and can be aligned with varied religious orientations. $^{39}$

Doctrinal Differences: This brings us to the question of possibly combining 3HO/KY practices with Christian religious orientations. As far as I can tell, there is nothing in traditional Christian practice that involves the body in such an active and potentially integrative movement with spiritual consciousness, so one can see why $3 \mathrm{HO} / \mathrm{KY}$ might be quite appealing to some Christians who are drawn towards a more embodied, mystical sense of spirituality. While it appears the strong stress in 3HO/KY on Sikh spirituality and ethos allow this yoga simply to skirt or to side step most of the criticisms raised against other western developed postural yoga schools, some issues will be associated with the way in which Christians practicing $3 \mathrm{HO} / \mathrm{KY}$ will need somehow to combine or incorporate this Sikh devotional foci with their Christian faith. In closing, I highlight two possible theological parallels for future comparative analysis, before closing with some brief reflections on issues surrounding "syncretism".

Apart from strong general affinities between the two traditions in areas of sociomoral life, there are obvious parallels to (1) Christian dogma in Sikh beliefs in divine Reality and among (2) Sikh beliefs in the historical Guru's perspectives and Christian attitudes towards the early apostles and other major saints, at least within certain denominations. In 
terms of the latter correspondence (2), intercessory prayer in both traditions focuses on significant historical figures thought to have special roles and powers in supporting the movement to spiritual "perfection" or liberation. It seems possible to me that Christians who advocate inclusivist or pluralist perspectives of religion might come to admire and perhaps even to venerate or honor certain Sikh Guru's-the ten founding historical spiritual teachers of Sikhism-as they encounter them in 3HO/KY. Or perhaps by observing how the Sikh Guru's are approached and regarded in $3 \mathrm{HO} / \mathrm{KY}$, they might gain different or deeper perspective on and appreciation for Christian saints.

With regard to the former parallel concerning divine Reality (1), Sikhs believe in the oneness of God as ultimate Truth, supreme and radically Transcendent, which is beyond time and space, self-existent, self-illumined, yet Who is also omnipresent creator Spirit, without fear and hatred, and infinitely grace-giving. Those are images that are chanted devotionally in the Mul Mantra, which opens Sikh sacred scripture, and is a popular $3 \mathrm{HO} / \mathrm{KY}$ mantra. Now, such conceptual imagery of the Divine is familiar to Christians, and perhaps it is even possible to view or conceive of the ultimate Guru within the framework of the Christian Trinity. This includes: the non-personal and timeless unitive essence of Sat Guru (like the Father, which is conceived in some Christian mystical theology as primary pure Being, the formless and transcendent Source of all creative movement and form); as well as God's personal outpouring in creative action (like the Word, who issues forth in structured and meaningful life, manifesting God's truth and goodness); and its omnipresent supportive and healing love in creation (like the Holy Spirit-as the indwelling, inspiring and empowering divine Presence). Indeed, there seem to be potentially striking parallels between the Reality of the Sikh Shabd Guru-the sacred sound of divine Reality-and the Christian creative Word, though the latter remains underdeveloped in Christian practice. It seems to me that the Sikh doctrine of ultimate Reality is very similar to Christian conceptions of God, even though there is no sense of historical Incarnation in the Sikh tradition.

However, this very possibility of integrating various mantric aspects of $3 \mathrm{HO} / \mathrm{KY}$ with Christian conceptions raises perhaps the main issue from the standpoint of Christian institutional authorities-the dangers of syncretism. For many religious theorists, syncretism can have the neutral or positive senses of incorporating new beliefs from another tradition or of integrating beliefs or practices from different traditions. From the perspective of Christian critics, syncretism is not always well defined, but I take it to mean an "unprincipled comingling" ${ }^{40}$ of religions, where non-Christian and Christian beliefs and practices come together in such a fashion that they deny or distort or contradict essential Christian teachings. If that is what is meant by syncretism, it seems to me that this is a real possibility for Christians practicing $3 \mathrm{HO} / \mathrm{KY}$, or for that matter, Christians practicing any religiously grounded yoga, as they work to integrate the positive aspects of yoga with their faith perspective. More generally, this kind of syncretism is an issue that people of religious faiths must navigate in their everyday encounters of all aspects of secular culture, as personal religious experience is always contextualized by one's socio-cultural categories of experience and interpretation. However, with respect to yoga, perhaps there 
are parallels here with issues Christians face in the practice of "multireligious" and "interreligious" prayer.

Some Christian theologians distinguish helpfully between the practice of multireligious prayer (where people gather together to pray prayers separately, each from their own specific traditions) and interreligious prayer (where people of different traditions gather together and share the same prayers). Commenting on these different kinds of prayer, Gavin D'Costa notes Roman Catholic Cardinal Ratzinger's concerns about multireligious prayer: "it almost inevitably leads to false interpretations, to indifference as to the content of what is believed or not believed, and thus to the dissolution of real faith". D'Costa also describes the critique by some Roman Catholic bishops of interreligious prayer, who claim that "we cannot literally pray together, because prayer is an expression of faith, and we do not share one faith". ${ }^{41}$

In response to such criticisms, I would simply point out that there are potentially great benefits to certain kinds of multireligious and interreligious prayer and there are significant commonalities amongst many different religious traditions-hence many shared elements of faith-despite the fact they are different faiths. So I would not agree that these general concerns raised against multireligious and interreligious prayer should lead us to abandon the practices. But such discussion stimulates questions for me related to yoga practice: How do the dynamics of people of various traditions who are praying together differ from that of people of different traditions who are practicing yoga together? Can we distinguish intelligibly between multireligious yoga and interreligious yoga? To what degree can or should a Christian participate in Indian religious beliefs and practices while she or he is doing yoga?

In beginning to respond to these questions, I would observe that Christian groups that integrate solely Christian doctrine with postural-type yoga-such as Holy Yoga and Yoga Faith-seem to reject interreligious yoga altogether, insofar as they explicitly attempt to strip certain physical aspects of yoga (posture, breath, meditation) from all non-Christian theory and theology-for example, from Indian religious views of ultimate Reality, anthropology and spiritual liberation. In the case of Christians practicing $3 \mathrm{HO} / \mathrm{KY}$, interreligious yoga practice is quite possible, insofar as the person might focus intentionally and prayerfully on the various spiritual teachings that accompany the physical activities of this yoga. At the end of section 2 of this essay, I raised practical questions which I think are relevant here in considering such interreligious dialogue of experience: (1) Do these yoga practices inspire and arouse beneficial types of embodied spiritual experiences that would not otherwise obtain? (2) Do they support or augment the experience and communication of the love of Christ? (3) Do they force one to contradict essential Christian practices and beliefs?

Responses to these questions will be articulated specifically in varied ways depending on many factors, for example: on how individuals have understood and appropriated Christian teachings-which shift, transform, and deepen over a person's lifetimeas well as on the particular attitudes, needs, and hopes of the individual, and on the approach to the yoga teachings in question. Speaking generally, I think Christians need to be mindful of the ways in which these yoga practices are 
affecting their physical, emotional, and spiritual wellbeing, as well as that of others, but such discernment depends on specific histories, circumstances, and interpretive contexts. In that regard, consultation with spiritual directors, guides, counselors, and therapists can be quite helpful. I should also say that, in my experience, authorities and teachers of $3 \mathrm{HO} / \mathrm{KY}$ never force a person to believe or to practice anything with which she or he is not comfortable, so a practitioner is always free not to practice or to ignore certain exercises, mantric-prayers, or interpretive commentary by teachers, and certainly some of them do.

Moreover, despite the dangers of syncretism-of instances where non-Christian and Christian beliefs and practices come together in a way that denies, distorts or contradicts essential Christian teaching-it

\section{Notes}

${ }^{1}$ Andrea R. Jain notes that the first "widely influential teachers" of modern postural yoga were Tirumalai Krishnamacharya (1888-1989) and Sivananda Saraswati (1887-1963) and their disciples (B.K.S. Iyengar, Patabhi Jois (Ashtanga Vinyasa), T.K.V. Desikachar, Vishnudevananda, and Swami Satyananda (Bihar), and Swami Satchidananda (Integral). Andrea R. Jain, “The Malleability of Yoga: A Response to Christian and Hindu Opponents of the Popularization of Yoga", Journal of Hindu-Christian Studies Vol. 25, No 4 (2012), 1-8.

${ }^{2}$ These groups include: Christians Practicing Yoga, Yoga Faith, Holy Yoga, Yahweh Yoga, Christian Yoga Magazine, and Jewish Yoga Network. On their websites, these groups provide various information about yoga theory and practice, details about classes and teachers, and typically some sense of the nature of their integration of yoga with Christian faith, including apologetic materials.

${ }^{3}$ I should note that I have been practicing regularly $3 \mathrm{HO} / \mathrm{KY}$ since 2007 , but my religious seems likely to me that current experiences by some Christians of $3 \mathrm{HO} / \mathrm{KY}$ and of other nonChristian yoga will have some positive bearing on the creative refinement of future Christian belief and practice, however minor or major these might be. I suspect, for example, that some Christian authorities might become more open generally to different kinds of yoga, perhaps even encouraging it, in light of its various positive effects, and that more and more Christians will come to pursue the practices. And I myself would also support some utilization of certain aspects of Indian theory in creatively refining Christian anthropology and eschatology, as well as the possibility that the kind of devotional chanting we find in this Sikh yoga be creatively adapted somehow to Christian practice.

background is Roman Catholic and my spiritual leanings are towards Ignatian spirituality with a mystical emphasis and openness to interreligious dialogue, especially to dialogue of religious experience. The paper is influenced somewhat by two of my published articles and an unpublished essay: "Embodied Spirituality in 3HO Kundalini Yoga and some Christian Inter-Religious Reflections", Vivekananda Review (forthcoming); "3HO Kundalini Yoga and Sikh Dharma", Sikh Formations, Vol. 8, No. 3 (2012) pp. 351-368; "Counter-Culture in the Reception of Kundalini Yoga in California: Hippies and and 3HO/Sikh Dharma".

${ }^{4}$ Paul Vitello, "Hindu Group Stirs a Debate Over Yoga's Soul”, New York Times, Nov. 27, 2010, New York Times http://www.nytimes.com/2010/11/28/ nyregion/28yoga.html?src=me\&ref=homepage

(accessed May 11, 2017).

5 http://www.cbc.ca/news/canada/ottawa/ university-ottawa-yoga-cultural-sensitivity-

1.3330441; (accessed May 11, 2017). 
https://www.therebel.media/university_of_ottawa_ bans_free_yoga_class_because_of_cultural appropriation (accessed May 11, 2017).

${ }^{6}$ https://holyyoga.net/about/what-we-believe/ (accessed May 11, 2017).

7 "Bikram Choudhury Net Worth", Celebrity Net Worth: http://www.celebritynetworth.com/richestbusinessmen/business-executives/bikramchoudhury-net-worth/. See also Endnote \#7.

${ }^{8}$ See: Stephen Ceasar, "Yoga guru Bikram Choudhury must pay $\$ 6$ million in punitive damages, jury decides", Los Angeles Time, January 26, 2016: http://touch.latimes.com/\#section/-1/article/p2p85700031/ (Accessed May 11, 2017); Carolyn Graham, "He's the flamboyant $£ 40 \mathrm{~m}$ 'hot yoga' guru who the celebs adore", Mail Online, January 31, 2017: http://www.dailymail.co.uk/news/article-3424686/ He-s-flamboyant-40m-hot-yoga-guru-celebs-adore5m-harassment-case-Bikram-Choudhury-s-Britishlawyer-says-s-just-seedy-sex-pest-pants.html (accessed May 26, 2017); and Josh King, "Calif. Judge issues arrest warrant for hot yoga founder Bikram Choughury", USA Today: http://www.usatoday.com/story/life/people/2017/ 05/25/calif-judge-issues-arrest-warrant-hot-yogafounder-bikram-choudhury/102136476/ (Accessed May 26, 2017).

${ }^{9}$ The issue of sexuality applies to a number of western Gurus and Yogis-including for example Rajneesh, Swami Muktanada, and Adi Da, who have been involved in sexual relations with students or devotees. I note also that Yogi Bhajan of $3 \mathrm{HO} / \mathrm{KY}$ has been accused of sexual misconduct in relation to some of his secretaries, though none of these charges have been proven. Also on this issue in relation to Yogi Bhajan, see endnote \#28.

10 http://indianyogafederation.com/index.php (Accessed May 11, 2017).

${ }^{11}$ Bradley Malkovsky, God's Other Children: Personal Encounters with Faith, Love, and Holiness in Sacred India (HarperOne, 2013), 137-138.

${ }^{12}$ Congregation for the Doctrine of the Faith, Joseph Cardinal Ratzinger, Prefect, "Letter to the Bishops of the Catholic Church on Some Aspects of
Christian Meditation" (October 15, 1989) par. 26. (http://www.vatican.va/roman_curia/congregation s/cfaith/documents/rc_con_cfaith_doc_19891015_m editazione-cristiana_en.html) (Accessed May 11, 2017).

13 CDF, "On Some aspects of Christian Meditation", par. 27.

14 CDF, "On Some aspects of Christian Meditation", par 28.

${ }^{15}$ As cited in Jain, "The Malleability of Yoga", p. 2, from a YouTube post. Also, see Andrea A. Jain, Selling Yoga: From Counterculture to Pop Culture (New York: Oxford Press, 2015), pp 137-138. Jain notes a comment by Gabriele Amorth, an Italian Roman Catholic priest and exorcist for the Diocese of Rome in 1986: "Practicing yoga is Satanic, it leads to evil...". 136. With regard to Christian critics of yoga, Jain also mentions Albert Mohler and Douglas Groothius, who accuse yoga of overriding scripture as "the means to understanding God" and for including depersonalizing and dehumanizing ideals and a view of the body in relation to the divine, which they claim is inherently anti-Christian and threatening to Christianity. See Jain, Selling Yoga, 138-140. See especially chapter 6 on these themes.

${ }^{16}$ Bradley Malkovsky, God's Other Children, 151152.

${ }^{17}$ Michael Washburn, The Ego and the Dynamic Ground: A Transpersonal Theory of Human Development, $2^{\text {nd }}$ rev. ed. (Albany: SUNY Press, 1995), 153-157. Valentin Tomberg, Meditations on the Tarot: A Journey into Christian Hermeticism, Robert A. Powell (Rockport, MA: Element, Inc., 1991), 155, 156.

$18 \mathrm{CDF}$, "On Some aspects of Christian Meditation", par. 14-15.

$19 \mathrm{CDF}$, "On Some aspects of Christian Meditation", par. 16.

${ }^{20}$ Thomas Matus, Yoga and the Jesus Prayer Tradition: An Experiment in Faith (New York: Paulist Press, 1984), 26, 9.

${ }^{21}$ Thomas Ryan's work has influenced my thought in this area. See Thomas Ryan, "Toward a Positive Spirituality of the Body", in Reclaiming the Body in Christian Spirituality, Thomas Ryan, ed. (New 
York: Paulist Press, 2005), 57-63. Also, I first propose versions of the practical questions \#1 and \#2 that I discuss here in "Embodied Spirituality in $3 \mathrm{HO}$ Kundalini Yoga and some Christian Inter-Religious Reflections", Vivekananda Review (forthcoming).

${ }^{22}$ P. K. Khalsa and S. K. K. Khalsa, The Man Called the Siri Singh Sahib, (Los Angeles: Sikh Dharma, 1979) 18-33; http://www.yogibhajan.com/About.htm (accessed July 4, 2017). Internet site accessed August 8, 2012. Today $3 \mathrm{HO}$ is referred to as " $3 \mathrm{HO}$ Foundation". It "is a 501(c)3 NPO and a NonGovernmental Organization (NGO) in consultative status with the Economic and Social Council (ECOSOC) of the United Nations." See http://www.3ho.org/about/ (accessed July 4, 2017).

${ }^{23}$ Guru Raj Kaur Khalsa, "Kundalinu Yoga and Sikh Dharma", in Victory and Virtue, Ceremonies and Code of Conduct of Sikh Dharma, Satkirpal K. Khalsa and Premka K. Khalsa, eds. (Los Angeles: Sikh Dharma), as cited by Shanit Kaur Khalsa, "Yogi Bhajan and the Emergence of Sikh Dharma International", in Sikh Formations, Vol. 8, No. 3 (December 2012), 397.

${ }^{24}$ "Sikh Dharma International": https://www.sikhdharma.org/sikh-dharmainternational/\#Mission (accessed May 16, 2017). In terms of governance, Sikh Dharma International (SDI) has eight Board Directors, eight Officers, an International Khalsa Council, and a Public Affairs Office. It is also characterized as a Sikh denomination whose mission is to "share the teachings and technology of Sikh Dharma as found in the Siri Guru Granth Sahib, the lives and teachings of the Sikh Gurus". It is registered in California and centered in New Mexico and gives special attention to the teachings of Yogi Bhajan. Official website commentary acknowledges: "Part of the primary mission of Sikh Dharma International is to preserve, organize and continue to share the teachings of the Sikh Gurus as described by the late Siri Singh Sahib [Yogi Bhajan] in his unique style. His way of talking and teaching about the path of the Sikh has, for the first time in history, made the Sikh faith accessible to people from every background, language, and culture of the world". From "Sikh Dharma Ministry": http://sdministry.org/sikh-dharma-international2/?issue=2017-spring (accessed May 11, 2017).

I should note that this authorization from the Akal Takhat and special attention and authority granted to Yogi Bhajan have come under criticism in some Sikh circles.

${ }^{25}$ From "Sikh Dharma International, Legacy Organizations": $\quad$ https://www.sikhdharma.org/ legacy-organizations/ (accessed May 19, 2017).

26 Pashaura Singh, "Re-imagining Sikhs ('Sikhiness') in the Twenty-First Century: Toward a Paradigm Shift in Sikh Studies", in Re-Imagining South Asian Religions: Essays in Honour of Professors Harold G. Coward and Ronald W. Neufeldt, Michael Hawley and Pashaura Singh, eds., ( Leiden, The Netherlands: Brill, 2013), 31. Also, Dusenbery writes: “Thus, for example, we see young Punjabi Sikhs joining with Gora Sikhs to challenge caste and gender discrimination in Sikh institutions and to introduce new religious practices (including multilingual religious services; new liturgical music forms; use of the Internet and youth camps to deliver religious education), as well as coming together to advocate for Sikh civil and religious rights in the larger society. Ironically, without the polarizing presence of Yogi Bhajan, some of his teachings and practices (including Kundalini Yoga classes, increasingly taught on gurdwara premises in the diaspora) may actually have more influence on Punjabi Sikhs than they did during his lifetime!". "3HO/Sikh Dharma: Some Issues for Consideration", Sikh Formations, Vol. 8, No. 3 (December 2012), 342.

${ }^{27}$ KRIITT, 100.

${ }^{28}$ These socio-moral features of 3HO/KY need to be set against the question of sexual impropriety on the part of Yogi Bhajan in relation to some of his secretaries, which I mentioned in endnote \#9. I think it is important to keep in mind that these charges have not been proven. However, regardless of the question of the status of such accusations against Yogi Bhajan, it is significant that there are moral guidelines built into this yoga school that function as significant protection against sexual improprieties 
and distortions amongst leaders, teachers, and students.

${ }^{29}$ The first level teacher training in Canada costs $\$ 3750$ CAN with annual membership fees currently at $\$ 120.00$ USD for Canada and USA and \$54 USD for Latin America, while teachers in Toronto typically charge for classes about $\$ 18$ CAN with five class passes around $\$ 85$. Compare roughly for example with Bikram Yoga training, with current costs at $\$ 16,600$ USD and recertification costs for every three years at $\$ 1200$ USD, both of which require travel to Acapulco.

${ }^{30}$ KRIITT, 293.

${ }^{31}$ The Sikh Dharma Library of Teachings website describes Yogi Bhajan as follows: "A graduate in Economics from Punjab University (1952) and a savvy entrepreneur he encouraged his students to start their own businesses. One of the first, Yogi Tea, brought his famous recipe into the mainstream, and it is now one of the leading tea companies in the health food market in the USA and Europe. $\mathrm{He}$ became a trusted management consultant for 14 corporations worldwide, representing industries as diverse as health food manufacturing (KIIT-Golden Temple Foods), computer systems (Sun and Son), and security services (Akal Security). He conducted business seminars and authored several books to guide the aspiring entrepreneur as well as the seasoned executive." See "The Yogi Bhajan Library of Teachings": https://www.libraryofteachings.com/ page.xqy?page=about-yb (accessed May 19, 2017).

${ }^{32}$ A 2007 report of a lawsuit between trustees and Inderjit Kaur Puri speak of conflicts over almost 7 million dollars, but it does not specify the total amount that Yogi Bhajan left in his will. Tom Sharpe, "Late Sikh leader's trustees, widow, at odds over estate", Santa Fe New Mexican, October 9, 2007. http://www.santafenewmexican.com/news/local_n ews/late-sikh-leader-s-trustees-widow-at-oddsover-estate/article_9c08559f-4466-5290-a2a8d316c4b7a7ee.html (accessed July 7, 2017).

${ }^{33}$ Internal struggles that arose amongst group executives when the Unto Infinity Board was accused of immoral and illegal financial dealings from which they profited, now seem to be settled. In 2009, the SDI religious leaders filed a lawsuit against the Unto Infinity Board for '“breach of fiduciary'-that the business leaders failed to protect the assets held in trust for the religious community" in regards to their sale of Golden Temple, of which now remains only Yogi Tea. In 2010 this lawsuit was expanded to include Golden Temple management and combined with a suit from Oregon Attorney General John Kroger. The suit was successful in 2011. Unto Infinity Board members have since been replaced and the court ordered Golden Temple executives to "return payments they wrongfully received from the company, estimated to total more than $\$ 30$ million". Information surrounding this and other issues surrounding the group was drawn from: Sherri Buri McDonald, "Golden Temple payback due: A judge drafts an opinion that Eugene company's top six executives must return more than $\$ 30$ million". The Register-Guard, Saturday, April 14, 2012, page A1, http://archive.li/x6c7C (accessed May, 16, 2017); and Sherri Buri McDonald, "Golden Temple Suits Merged", The Register-Guard, Saturday, December 11, 2010, Page B4, http://projects.registerguard.com/ $\mathrm{csp} / \mathrm{cms} / \mathrm{sites} / \mathrm{web} / \mathrm{business} / 25652560-41 /$ templejudge-religious-attorney-bhajan.csp, (accessed May, 16, 2017); Sherri Buri McDonald, “\$4 Million man", The Register-Guard, May 12, https://www.sikhphilosophy.net/threads/4million-man.35379/ (accessed May 19, 2017); Paul Elias, "Espanola-based Akal Security Faces Legal Issues", Albuquerque Journal, October 8, 2012, https://www.abqjournal.com/136737/espanolabased-akal-securities-faces-legal-issues.html, (accessed May 19, 2017); Kamalla Kaur, “Yogi Bhajan's Dharma to Receive at least \$30 Million", May 16, 2012, www.sikhfreepress.org; http://sikhfreepress.org/ headlines/1805/yogi-bhajan\%E2\%80\%99s-dharmareceive-least-30-million (accessed May 16, 2017); and Pamela Chestek, "When Trademark and Estate Don't Mix" (November 24, 2014): http://property intangible.com/2014/11/ when-trademark-andestate-dont-mix.html (accessed May 26, 2017). 
${ }^{34}$ Leslie Wayne, "Sikh Group finds Calling in Homeland Security", New York Times, September 28, 2004, $\quad$ http://www.nytimes.com/2004/09/28/ business/sikh-group-finds-calling-in-homelandsecurity.html (accessed May 16, 2017); and Renee Blake, "Sikh Approach to Modern Security Needs Means Big Business in Small New Mexican Town, Voice of America, September 28, 2004, http://www.voanews.com/a/a-13-2005-03-17voa30-67381032/274749.html (accessed March 17, 2005); and Nicola Mooney, "Reading Weber Among the Sikhs: Asceticism and Capitalism in the 3HO/Sikh Dharma", Sikh Formations, Vol. 8, No. 3 (December 2012), 417-436, esp. 427-428.

35 See Mooney, "Reading Weber Among the Sikhs", 428; and Kirpal Singh Khalsa, "New Religious movements Turn to Worldly Success", Journal for the Scientific Study of Religion, Vol. 25, No. 2 (1986), 233-47.

${ }^{36}$ KRIITT, 272.

${ }^{37}$ For discussion of these scriptural references, see Michael Stoeber, "3HO Kundalini Yoga and Sikh Dharma”, Sikh Formations, especially 358, 365, and endnote 18.

${ }^{38}$ Philip Deslippe refers to books that illustrate hatha yoga practices by the Hindu Swami Dhirendra Brahmachari, Yogāsana Viñāana: The Science of Yoga (New Delhi: Asia Publishing House, 1970) and Yoga: Yoga Sūkşma Vyāmā (New Delhi: Indian Book Company, 1970 [1965]) and the teachings related to mantras and chanting of Sikh Sant Maharaj Virsa Singh ("From Maharaj to Mahan Tantric: The Construction of Yogi Bhajan's Kundalini Yoga", Sikh Formations, Vol. 8, No. 3 (2012), 369-387). However, the questions surrounding Deslippe's thesis is that Yogi Bhajan's 3HO/KY includes many practices that one does not find in these books and many mantras beyond that ascribed to Maharaj Vira Singh, suggesting further sources for $3 \mathrm{HO} / \mathrm{KY}$ beyond these two. Moreover, Shanti Kaur Khalsa suggests plausibly that any traditional Sikh yoga would have been suppressed in the second half of the $19^{\text {th }}$ century as inappropriately Hindu by the Tat Khalsa, a reform movement that sought to distance Sikhism from Hinduism in the face of British definitions of Sikhism as a Hindu sect, which would account for the apparent modern disconnect of yoga from mainline Sikhism ("Yogi Bhajan and the Emergence of Sikh Dharma International", Sikh Formations, Vol. 8, No. 3 (December 2012), 396.) In sum, I would say it is more likely that Yogi Bhajan had many yoga teachers (including some Sikhs) and access to various Kundalini Yoga texts. I also suspect that some form of Kundalini Yoga was practiced by some Sikhs at the very beginning of the tradition, given the Nath influences on Sikh spirituality, however minor this stream might have been.

${ }^{39}$ Jain, Selling Yoga, especially 158-160; Mark Singleton, Yoga Body: The Origins of Modern Posture Practice (New York: Oxford University Press, 2010); Elizabeth de Michelis, A History of Modern Yoga: Patanjali and Western Esotericism (New York: Continuum, 2004).

${ }^{40}$ Carl Starkloff, A Theology of the In-Between (Miwaukee, Wisconsin: Marquette University Press, 2002), 145.

${ }^{41}$ Gavin D'Costa, "Interreligious Prayer Between Roman Catholic Christians and Muslims", in Religious Participation and Interreligious Dialogue, Mariann Moyaert and Joris Geldhof, eds. (New York: Bloomsbury, 2015), 100, 99. 